Journal of Social Sciences (COES\&RJ-JSS)

ISSN (E): 2305-9249 ISSN (P): 2305-9494

Publisher: Centre of Excellence for Scientific \& Research Journalism, COES\&RJ LLC

Online Publication Date: $\mathbf{1}^{\text {st }}$ July 2020

Online Issue: Volume 9, Number 3, July 2020

https://doi.org/10.25255/jss.2020.9.3.1295.1319

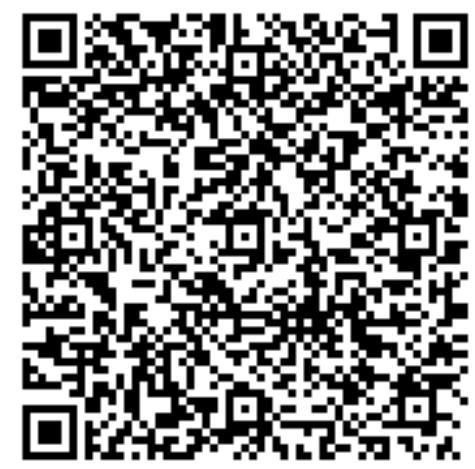

\title{
The significance of mega sporting event on infrastructure development: A case of FIFA 2022 World Cup in Qatar \\ Khalifa Al-Dosari
}

Brunel University, London, UK

khalifaaldosari@hotmail.com

\begin{abstract}
:
This study sought to find how significant mega sporting events to a country are beneficial insofar as infrastructural development is concerned. The study used the 2022 FIFA World Cup in Qatar as the case study in reference. Various researches around the concept of infrastructure development due to mega sporting events were analysed in this study. The evidence of infrastructure development due to mega sporting events was also dissected and presented in the study. The research was conducted with the help of online survey questionnaires, and the data collected was analysed by using descriptive statistics as well as an OLS regression analysis. The variables measured were infrastructural developments in the country to find the significance of the 2022 FIFA World Cup. It was found that the 2022 World cup significantly affects the development of infrastructure in the country. It was therefore concluded that major sporting events are significant in the development of infrastructure of a country. It's recommended that the research should be used for future references in the analysis of infrastructural changes due to major sporting events.
\end{abstract}

\section{Keywords:}

2022 FIFA World Cup, Infrastructural Developments, Regression Analysis, Mega sporting events model, SPSS

\section{Citation:}

Al-Dosari, Khalifa (2020); The significance of mega sporting event on infrastructure development: A case of FIFA 2022 World Cup in Qatar; Journal of

\footnotetext{
This work is licensed under a Creative Commons Attribution 4.0 International License.
} 
Social Sciences (COES\&RJ-JSS), Vol.9, No.3, pp:1295-1319; https://doi.org/10.25255/jss.2020.9.3.1295.1319.

\section{INTRODUCTION}

\section{The Background and Context of Research}

The FIFA (International Federation of Association Football) world cup began in 1930 and has been named the most prestigious football tournament in the world ${ }^{1}$. Qatar was announced as the host for the 2022 FIFA world cup tournament in the year 2010 after winning in the voting process. Major sporting events have proven to be a big deal over time and especially the world cup. This has meant that most countries have tried to enhance their economies to be more attractive to major sporting events ${ }^{2}$. According to the United states sports academy, ${ }^{3}$ the United States being among the countries that had made a bid to hold the 2022 world cup, had been seen to attract major sports teams by building better sports infrastructure facilities. European countries are also among countries that are seen to make advancements to host major sporting events. Countries like Croatia were seen to engage significantly in hosting the UEFA champions' league, ${ }^{4}$ a major sports event, by emphasising their urban regeneration in their major cities. Over the years, hosting the FIFA world cup has been done by industrialised countries, and the need for equality in nations has however risen.

Hosting the world cup 2010 by South Africa, however, opened the doors for considering other developing countries. South Africa saw a significant improvement in its transportation systems ${ }^{5}$. New airports were opened, and various bus transit systems were constructed in major cities. The areas around the world cup stadium were turned into a fan park for its citizens, and most other public places were revolutionised. South Africa having recovered from a discriminatory apartheid regime, showed great improvement in its infrastructure. The implication is that Qatar should be able to improve significantly in infrastructure. Moreover, the pressure from the FIFA world cup for Qatar to increase its security creates the need for better surveillance facilities in the country. Also, for a long time, Qatar lacked the presence of well-known

${ }^{1}$. Dunmore, Tom, Historical dictionary of soccer. (Scarecrow Press, 2011)

2. Šimić-Banović, Ružica, Ana Jurčić, and Milan Petronijević. "Hosting mega sport events in a small country: The (real) impact on the development-cases of Croatia and

Serbia." Megatrend revija 14, no. 2 (2017)

${ }^{3}$. Robby Robertson, the Economic Impact of Sports Facilities, "United States Sports

Academy-" America's Sports University." (The Sport Digest - ISSN: 1558-6448)

4 "History - Croatian Football Federation ". 2020. Hns-Cff.Hr. https://hns-

cff.hr/en/hns/about-us/history/

5 . Nate Berg, The Infrastructural Benefit of South Africa's World Cup, 2010. 
international competitions in football games ${ }^{6}$. This has been coupled with a lack of quality stadiums due to football inefficiencies. Even with football being the lead sport in the country, it lacks proper sporting facilities. The presence of the extreme heat conditions in the country cannot be left behind, ${ }^{7}$ hence there is the need for building better facilities to cater for the shortfalls of harsh weather during mega sporting events.

Qatar, however, benefits from being an oil-producing country and having a large GDP capacity. This implies that Qatar can be able to reinvent the country's infrastructure. The country, compared to other developed countries such as the U.S, has an inadequate telecommunication infrastructure. The country only has 2 Television stations and one internet service provider ${ }^{8}$. The country also records very low numbers of internet users and cell phone usage. With the World Cup requiring an extensive coverage of the event, this could deem to be overwhelming for one telecommunication service provider in the country. Therefore, there is a need to open up the telecommunication infrastructure to support the FIFA World Cup. The study, therefore, looked into the infrastructural developments taking place in Qatar and sought to establish its relationship with the 2022 FIFA World Cup. With the need for identifying the significance of major sporting events to infrastructure development, this research conducted theoretical and empirical studies on various literature of a similar nature. The study also analysed data collected through multiple tests and came up with the conclusion to its research objectives.

\section{Research Rationale}

FIFA is among the many organisations that are putting pressure to see how Qatar handles the 2022 World Cup ${ }^{9}$. The country, therefore, is obliged to adhere to various standards of the countries chosen to host the World Cup. This paper sought to identify whether Qatar has found it significant to enhance its infrastructure before the 2022 World cup. The study is significant to countries willing to host the World Cup and other developing nations that will be able to use Qatar as a reference for infrastructural changes needed to be made to host mega sporting events. The study also identified the demographics of Qatar as a nation and opened it's up to global standards. Fundamentally, this study shows

${ }^{6}$. Joan C. Henderson (2014) Hosting the 2022 FIFA World Cup: opportunities and challenges for Qatar, Journal of Sport \& Tourism, (19:3-4, 281-298),

${ }^{7}$ Adam Rasmi, Beer is giving 2022 World Cup host Qatar a headache, (2019) https://qz.com/1663896/beer-is-giving-2022-world-cup-host-qatar-a-headache/

8. "Qatar Infrastructure, Power, and Communications, Information about Infrastructure, Power, and Communications in Qatar". 2020. (Nationsencyclopedia.Com.)

9. 2022 FIFA world cup awarded to Qatar, Dec 2010: Retrieved from https://www.fifa.com/news/2022-fifa-world-cup-awarded-qatar-1344500 
the relevant areas of development for the country and also identifies its strengths and in doing so, enables Qatar to attract visitors from other countries.

\section{The Aims and Objectives of the Research}

This research aimed to identify the significance of mega sporting events, in this case, the 2022 world cup, on infrastructural development in the host country, Qatar. To achieve this, the study was governed by the following objectives:

1. To provide an understanding of how the infrastructural developments are affected by mega sporting events.

2. To analyse the contribution of the 2022 FIFA World Cup to the infrastructural development in Qatar.

3. To assess how significant the effects of the 2022 FIFA world cup (FWC) could be in Qatar.

\section{Research Questions}

1. To what extent is the infrastructure developments in Qatar influenced by the 2022 FWC?

2. What is the association between the 2022 FIFA World Cup and the infrastructural development in Qatar?

3. How significant is the 2022 FIFA World Cup to the infrastructural development of Qatar?

\section{Significance of the Research}

Emerging researches on the infrastructural effects of mega sporting events have been on the rise. This research, therefore, adds to the existing research with the World cup as the new variable. This research, therefore, will be used as a reference for further study by other World cup hosting countries. Existing research has also failed to provide the significance of mega sporting events on infrastructure. This research will, therefore, be able to identify the existence of its significance to a new case study, Qatar. Moreover, various gaps have been identified in this study within the literature review: one, the lack of studies on many developing nations that have hosted major sporting events. There was also not a finite conclusion on the significance of the mega sporting events on infrastructure because most research papers their results were not quantified on whether the impacts were more positive or negative. The identified gaps helped to achieve the goals of this study and provided a reference for future studies. 
The significance of mega sporting event on infrastructure development: ...

\section{LITERATURE REVIEW}

\section{Infrastructural Development}

A theory of infrastructure development analysed by Agenor ${ }^{10}$ shows how efficient infrastructure development with the elimination of unnecessary expenditure finances will cause the economic growth of a country. With this research, it was determined that there is a significance of the changes made in infrastructure development. Matheson ${ }^{11}$ did a study on costs of infrastructure, the returns on the infrastructure changes and the long term benefits on urban development patterns. His research was theoretical and relied on previous literature to make conclusions. His case studies included the 2010 FIFA world cup in South Africa and other world cups such as the Korean, Japan and the US world cup. He also used the Summer Olympics hosted in Sydney. According to Matheson, ${ }^{12}$ mega Sports events impact a nation with higher infrastructural costs and lower rewards. The rewards are even lower in developing countries. There is not a clear distinction between sports infrastructure and non-sports infrastructures such as tourism and transportation infrastructure ${ }^{13}$. In his research, Matheson stated that the revenue collected from mega sports events could not be able to match up with the enormous expenditures involved in infrastructure development and therefore, not worth it.

Research by Chen Ling on the Beijing Olympics 2008 was conducted on the infrastructure of their traffics and stadiums. The study focussed on both qualitative and quantitative research to achieve its objectives. The study concluded that mega sporting events are considered when developing infrastructural changes in the city. According to the study, traffic, housing, and stadium conditions are essential in portraying a good image to the foreign inhabitants during the Olympics. The transportation systems would also be made reliable and efficient to ferry the athletes and the tourists to the Olympic venues $^{14}$. Fourie et al. ${ }^{15}$ however in their paper concluded that the economic

\footnotetext{
${ }^{10}$. Agénor, Pierre-Richard. (2010). A Theory of Infrastructure-Led Development. Journal of Economic Dynamics and Control. 34. 932-950. 10.1016/j.jedc.2010.01.009.

${ }^{11}$. Matheson, Victor, "Assessing the infrastructure impact of mega-events in emerging economies" (2012). Economics Department Working Papers. Paper 8. http://crossworks.holycross.edu/econ_working_papers/8

12. Ibid

${ }^{13}$ Baade, Robert A., Robert W. Baumann, and Victor A. Matheson. "Assessing the economic impact of college football games on local economies." Journal of Sports Economics 9, no. 6 (2008): 628-643.

${ }^{14}$. Fourie, Johan, and Maria Santana-Gallego. "The impact of mega-events on tourist arrivals." Stellenbosch, Stellenbosch University (2010).

${ }^{15}$. Ibid
} 
impact of mega sporting events would depend on the type of mega sporting event, the season that the event would take place, the countries participating in the event and its level of infrastructural development of the host country. Another review ${ }^{16}$ stated that World Cup events should only be held in countries with developed economies. This was due to the difference in the country revenue models of infrastructure.

\section{Associations Between Infrastructural Development and Mega Sporting Events}

Research by Chaberek ET. Al. ${ }^{17}$ identified that preparations for hosting mega sporting events have substantial effects on infrastructural development. However, the effects are not straightforward. The research focused on the analysis of literature involved with the European Football Cup of 2012 that was hosted by Poland and the 2014 World Cup in Brazil. The paper emphasised on the social impacts of hosting mega sporting events and that the economic developments of these events should not be limited to tourism, employment opportunities and infrastructure development. The researchers also noted that most countries are involved in hosting mega sports events due to the political achievements it comes with and not for the infrastructural benefits that are involved. Research by Gong, ${ }^{18}$ also states that policymakers will turn a blind eye to the higher costs of infrastructural developments. This is because of the boost in political careers and hence a higher foreign currency for the country. This study highlights both the positive and negative effects of mega sporting events. It's, however, highlights more of the positive impacts such as the \$24.8 billion impact for Japan during the 2002 world cup. This, in addition to the $\$ 8.9$ billion positive impacts on South Korea during the 2002 World Cup ${ }^{19}$.

The political benefits are seen to drive further the benefits of hosting the FIFA World Cup, such as the Russian World Cup. According to the OSW ${ }^{20}$ the 2018

\footnotetext{
16. "Hosting Mega Sporting Events - A Boost For the Host Nation's Economy?"

2018. Medium. https://medium.com/@valustrat/hosting-mega-sporting-events-a-boost-forthe-host-nations-economy-af0df5e95874.

${ }^{17}$. Chaberek-Karwacka, Grażyna, and Julia Ziółkowska. "The impact of mega events on the local economic development through the development of social capital." Journal of Geography, Politics and Society 7, no. 4 (2017): 25-31. 10.4467/24512249JG.17.034.7634

${ }^{18}$. Gong, Qi. "The Positive and Negative Economic Contributions of Mega-sporting Events to Local Communities." (2012).

${ }^{19}$ Finer, J. (2002, March 7). The grand illusion. Far Eastern Economic Review, 165 (9), (pp. 32-36)
}

1.1.1.1 ${ }^{20}$ "The 2018 FIFA World Cup In Russia - Circuses Instead Of Bread?" 2018. OSW Centre for Eastern Studies. https://www.osw.waw.pl/en/publikacje/oswcommentary/2018-09-17/2018-fifa-world-cup-russia-circuses-instead-bread. 
FIFA World Cup in Russia was the most expensive World Cup in history, this, however, did not stop the government from hosting the event. Most of the infrastructural changes, such as transportation and stadium developments, were covered by the government. However, the contractors that we're able to grab these tenders were companies controlled by Vladimir Putin's. The research stated that the tourist influx during the World cup was not any different from the previous. The country also had a very slight increase of $3 \%$ in transportation revenue. The infrastructure changes may not be able to last for its economy due to the high costs of maintenance that will come after it. Gouher et al. ${ }^{21}$ conducted a study with 155 participants to establish the business effects of mega-sporting events on local communities. He collected data by the use of questionnaires and came up with the opinions of the participants on the positive and negative effects of the mega sporting events (MSE). The research concluded that MSEs have positive impacts on the host cities through the increase of tourists, the development of infrastructure and the positive image of the country.

\section{Significance of Mega Sporting Events to Infrastructural Development}

Research by Mavropoulou et al. ${ }^{22}$ on the New Belgrade summer cup handball 2018 was conducted to show the impact of this mega sporting event to the city of Belgrade. They had a sample of 87 people including coaches, parents and other escorts of the event. They conducted a sample survey using a small-scale service quality questionnaire. The results show that the entire city of Belgrade was satisfied with the competition and they put emphasis on infrastructural developments related to the tournament. Research by Banovic et. $\mathrm{Al}^{23}$. On the post and pre analyses of hosting mega sports events showed a failure in countries Serbia and Croatia, to benefit from the hosting of the UEFA and handball's champions leagues. The research highlights the significant aspects of planning of sporting events and the fact that the costs in most of the cases

${ }^{21}$. Amponsah, Christian Tabi, Gouher Ahmed, Manoj Kumar, and Samuel Adams. "The business effects of mega-sporting events on host cities: an empirical view." Problems and Perspectives in Management 16, no. 3 (2018): 324-336. Retrieved from:

http://dx.doi.org/10.21511/ppm.16(3).2018.26

22. Angeliki, Mavropoulou, Hatzimanouil Dimitrios, Gkagkanas Kostas, and Kanioglou Aggelos. "Evaluation of the new Belgrade summer cup handball 2018 and the impact in the city of Belgrade." Journal of Physical Education 5, no. 2 (2018): 1-8., Published by American Research Institute for Policy Development https://doi.org/10.15640/jpesm.v5n2a1

23. Šimić-Banović, Ružica, Ana Jurčić, and Milan Petronijević. "Hosting mega sport events in a small country: The (real) impact on the development-cases of Croatia and Serbia." Megatrend revija 14, no. 2 (2017) 
outweigh the benefits of hosting the mega sporting events. The data in this study was majorly from existing theories and the empirical evidence collected after the major sporting events. The researchers conclude that there exist many deficits in the benefits of hosting mega sporting events. This was also backed up by Robert \& Matheson, ${ }^{24}$ in their quest to find out the impacts of mega sporting events on infrastructural development. They urge hosts of these events to consider whether hosting the events would be a burden or a blessing. This is because from their analysis of the literature reviews they identify countries like the US, after their 1994 World Cup, the host cities experienced a magnitude of losses between $\$ 5.5$ billion and $\$ 9.3$ billion. This was the opposite of the predicted estimated gains of $\$ 4$ billion and infrastructural development before the World Cup.

\section{Summary}

The chapter reviews studies on the various forms of infrastructural developments encountered in the host cities of these mega sporting events. It also identifies the difference in infrastructure changes experienced in different host countries. Moreover, the study depicts how significant the infrastructural effects are post and pre-occurrence of the mega sporting events. The studies by Victor Matheson ${ }^{25}$ does not depict the distinction between the different infrastructural developments influenced by mega sporting events. These studies also conclude that the costs of mega sporting events on the infrastructure of the host city outweigh the benefits. This is also in accordance with the research by Banovic et al. $^{26}$ on hosting of mega sporting events in Serbia and Croatia. Research by Chaberek et. Al. ${ }^{27}$ and Gong $^{28}$ showed the positive impacts of infrastructural development even with the high infrastructural costs. Other studies, like Mavropoulou et al., ${ }^{29}$ in Belgrade, found that mega sporting events boosted their city's infrastructure image and that helped boost their economy. This included Gouher et al. $^{30}$ and Chen Ling ${ }^{31}$ on the Beijing Olympics, who highlighted the positive effects of mega sporting events to cities.

\footnotetext{
${ }^{24}$. Baade, Robert A., and Victor A. Matheson. "The quest for the cup: assessing the economic impact of the world cup." Regional studies 38, no. 4 (2004): 343-

354., DOI: $10.1080 / 03434002000213888$

25. Matheson, Victor, (2004, 2008, 2012).

${ }^{26}$ Šimić-Banović, Ružica, Ana Jurčić, and Milan Petronijević. (2017)

${ }^{27}$. Chaberek-Karwacka, Grażyna, and Julia Ziółkowska (2017)

${ }^{28}$. Gong, Qi. "The Positive and Negative Economic Contributions of Mega-sporting

Events to Local Communities." (2012).

${ }^{29}$. Angeliki, Mavropoulou et. Al. (2018).

${ }^{30}$ Amponsah, Christian Tabi, Gouher Ahmed, Manoj Kumar, and Samuel Adams. "The business effects of mega-sporting events on host cities: an empirical view." Problems and Perspectives in Management 16, no. 3 (2018): 324-336. Retrieved from: http://dx.doi.org/10.21511/ppm.16(3).2018.26
} 
The significance of mega sporting event on infrastructure development: ...

\section{RESEARCH METHODOLOGY}

\section{The Research Design}

This study adopted a quantitative research design. The design used was in the form of experimental designs to establish the relationship between the infrastructural developments and mega sporting events, in this case, the 2022 FIFA World Cup (FWC). The design used identified the infrastructural changes experienced in Qatar with the announcement of the country as a host for the 2022 FWC. The quantitative design was chosen because, with numerical data, it was easier to make decisions for similar future conditions. The research incorporated the case study design by using the 2022 FWC. This approach enabled the researcher to use a variety of sources to conduct the research and also add more knowledge to what is previously known about the subject matter. With both experimental and case study designs, the research provided a clear understanding of the significance of the 2022 FWC on its host country, Qatar. ${ }^{32}$

\section{Sources of Data and Data Collection Method}

The study used the survey approach to collect data. Data was obtained primarily by the use of online survey-questionnaires. This method was employed due to how easy it is to use, and it can get to a larger geographical area, especially during this Covid-19 pandemic and the need for social-distancing. It is also very fast to send to the participants, hence it is less time-consuming. ${ }^{33}$ The method also helped in providing comprehensive and detailed responses from the participants due to its anonymity and confidentiality. A pilot study was first conducted to test the ambiguity and conformability of the questionnaires. The responses proved to be reliable with no concerns, hence the research questionnaire did not need to be changed. The sample of participants chosen came from different demographics. The participants chosen included; construction workers and skilled labours, project managers, volunteers from the local communities and government officials. 150 respondents were selected and the questionnaires sent to them. Only 72 responses were sent back. The entire process of design and data collection took one month, and the accuracy, validity and reliability of the data were ensured. The questionnaire included questions to determine the extent of infrastructure development on a 5-point Likert scale, with 1 as strongly disagree and 5 as strongly agree.

\footnotetext{
${ }^{31}$. Ling, Chen. "Mega-events and infrastructure improvements: The Case of the Olympic Games in Beijing 2008." (2007). Retrieved 26 April 2020, from https://lup.lub.lu.se/student-papers/search/publication/1325053

32 . Gravetter, Frederick J., and Lori-Ann B. Forzano. Research methods for the behavioural sciences. Cengage Learning, 2018.

${ }^{33}$ Ibid, 14
} 


\section{Methods of Data Analysis}

The Statistical tools used to analyse the data and evaluate the responses efficiently were SPSS packages. Data was put through a process of descriptive statistics as well as establishing the statistical significance of the variables using hypothesis testing. The data was put through an OLS regression model to obtain the results of the intended research questions. The results of the data were presented in the form of tables and graphs for easier data visualisations.

\section{The Research Hypothesis}

The tests performed to establish the research problems were as follows:

$\mathrm{H} 1$ : Mega sporting events do not increase the rate at which infrastructural developments take place in host cities.

H2: Infrastructural developments of host countries are affected negatively by mega sporting events

H3: Infrastructural developments of host countries are affected negatively by the costs expenditure of hosting mega sporting events

H4: The social and political infrastructure developments of host cities are affected negatively by Mega-sporting events

\section{Research Models Employed to Attain all the Research Objectives}

The model obtained was used to determine whether the mega sporting events had various effects on infrastructural developments with factors such as economic and social impacts considered as control variables. The conceptual model is shown in the figure below.

Figure 1 Mega Sporting Event Model

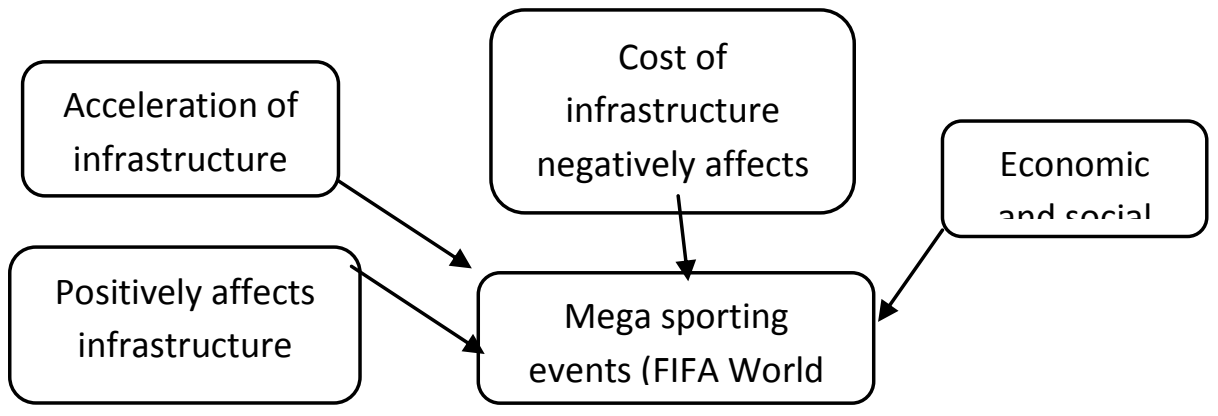

\section{Ethical Considerations}

The study paid great attention to seeking permits from all the relevant authorities involved in the management of the workers and officials questioned. The study also provided consent for the use of the data for only the purpose of this study. The respondents were assured that their information would be stored confidentially by the researcher. Their anonymity too was guaranteed by the researcher who ensured that participants were voluntarily participating in the 
research. The study would remain generalised, and the results would not reflect on any particular respondent.

\section{Research Limitations}

The research faced the limitation of sample size due to the availability of willing respondents during this Covid-19 pandemic. Also, the use of English Language to formulate the questionnaire was a limitation because Qatar being an Arabic speaking country, some participants, though willing to participants did not take part as a result of the language barrier. There was also the fear of respondents of who might be handling their responses and how their responses would personally affect them. Besides, the literature review was limited due to the lack of studies on many developing nations that have hosted major sporting events. There was also not a finite conclusion on the significance of the mega sporting events on infrastructure because most research papers their results were not quantified on whether the impacts were more positive or negative.

\section{ANALYSIS, RESULTS AND DISCUSSION \\ Data Analysis}

Changes in GDP and changes in government spending

The changes in Qatar's Gross Domestic Product (GDP) and the level of infrastructure using government spending were measured. This was to find out whether there have been changes since the announcement of the country as the host for the 2022 FIFA World Cup in the year 2010 . Figure 2 below shows that there was a considerable increase in the GDP of the country for the year 2010 compared to 2018 compared to the previous years. This change is seen to correspond directly with government spending (Fig 3). This, therefore, means an increase in infrastructure development in the country will have an equally positive effect on the GDP of the country.

\section{Figure 2 GDP Changes in Qatar}

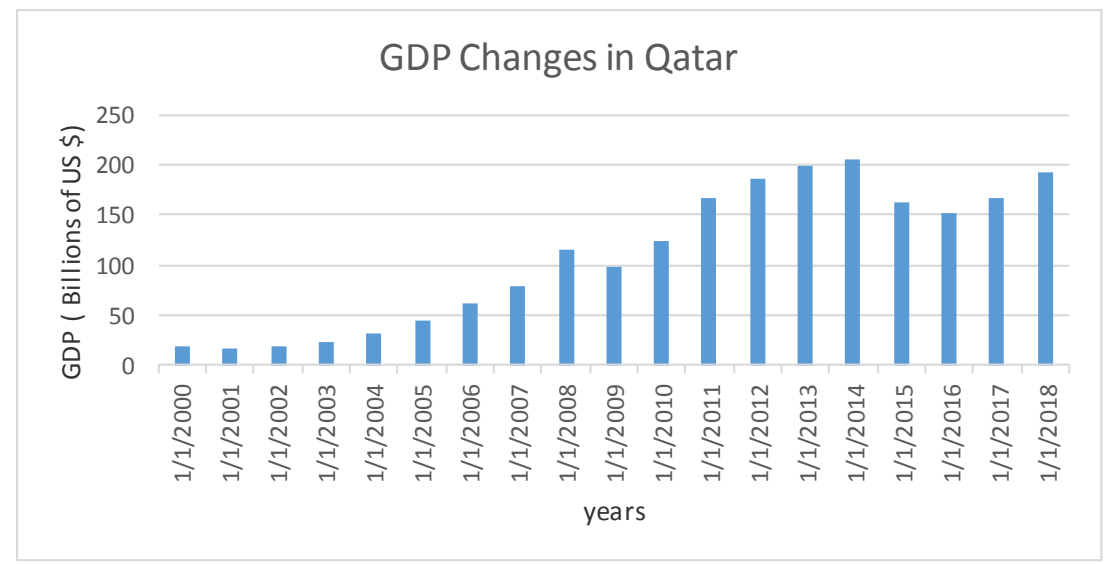


Figure 3 Government Spending

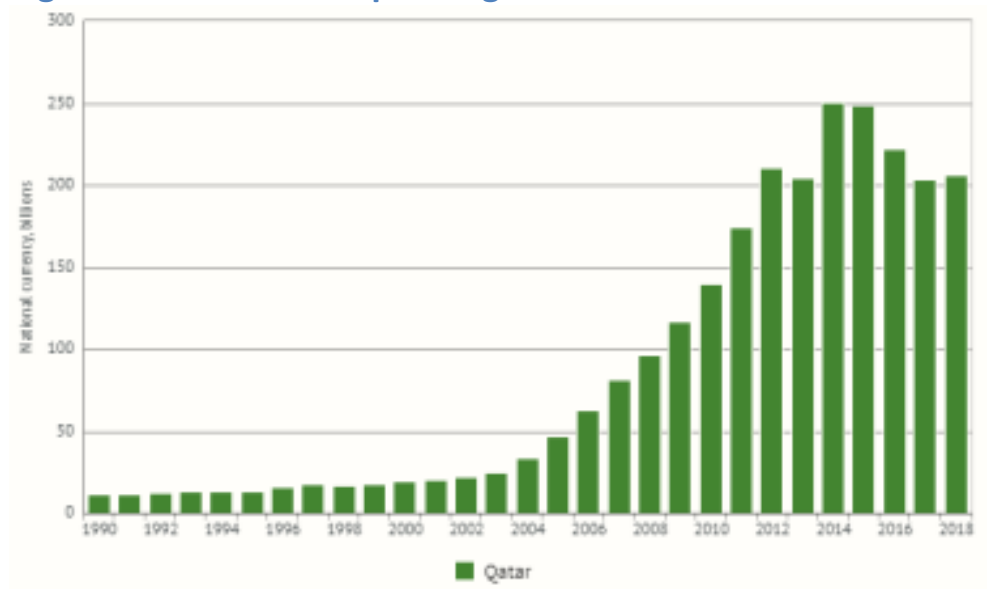

\section{Demographic Representation}

The different demographics of the participants were analysed and the detailed data presented in table 1 below. The majority of the respondents were between the ages of 26 and above. However, a higher percentage was those who were above 36 years at $48 \%$. Those between 26 and 35 were 34\%, and those between 18 and 25 were $16 \%$. Male respondents were more than female respondents at $61 \%$ and $39 \%$ respectively. A majority of the respondents were learned with the highest percentage being university-level graduates at $62 \% .30 \%$ had their master's degree, $4 \%$ with their doctorate degrees and $3 \%$ were high school graduates. The occupations were very diverse, but a more significant percentage were those with blue-collar jobs grouped as elementary occupations (26\%), skilled labourers (22\%), social workers (19\%), and service and sales workers (12\%). The white-collar jobs were $20 \%$, with professionals at $10 \%$ and government officials at $10 \%$. The scarcity of the professionals and the government officials was due to their scarce availability and the nature of their jobs. 
The significance of mega sporting event on infrastructure development: ...

Table 1 Demographic Representation

\begin{tabular}{|c|c|c|c|c|}
\hline \multicolumn{5}{|c|}{ Demographic distributions } \\
\hline \multicolumn{5}{|l|}{ Age } \\
\hline & Frequency & Percent & \begin{tabular}{|l|} 
Valid \\
Percent
\end{tabular} & Cumulative Percent \\
\hline $18-25$ & 12 & 16.7 & 16.7 & 16.7 \\
\hline $26-35$ & 25 & 34.7 & 34.7 & 51.4 \\
\hline $36+$ & 35 & 48.6 & 48.6 & 100.0 \\
\hline Total & 72 & 100.0 & 100.0 & \\
\hline \multicolumn{5}{|l|}{ Gender } \\
\hline Male & 44 & 61.1 & 61.1 & 61.1 \\
\hline Female & 28 & 38.9 & 38.9 & 100.0 \\
\hline Total & 72 & 100.0 & 100.0 & \\
\hline \multicolumn{5}{|l|}{ Level of education } \\
\hline $\begin{array}{l}\text { University } \\
\text { level }\end{array}$ & 45 & 62.5 & 62.5 & 62.5 \\
\hline $\begin{array}{l}\text { Master's } \\
\text { level }\end{array}$ & 22 & 30.6 & 30.6 & 93.1 \\
\hline PHD level & 3 & 4.2 & 4.2 & 97.2 \\
\hline $\begin{array}{l}\text { high school } \\
\text { graduate } \\
\text { level }\end{array}$ & 2 & 2.8 & 2.8 & 100.0 \\
\hline Total & 72 & 100.0 & 100.0 & \\
\hline \multicolumn{5}{|l|}{ Occupation } \\
\hline $\begin{array}{l}\text { Elementary } \\
\text { occupations }\end{array}$ & 19 & 26.4 & 26.4 & 26.4 \\
\hline $\begin{array}{l}\text { Skilled } \\
\text { labourers }\end{array}$ & 16 & 22.2 & 22.2 & 48.6 \\
\hline $\begin{array}{l}\text { Social } \\
\text { workers }\end{array}$ & 14 & 19.4 & 19.4 & 68.1 \\
\hline $\begin{array}{l}\text { service and } \\
\text { sales } \\
\text { workers }\end{array}$ & 9 & 12.5 & 12.5 & 80.6 \\
\hline Professionals & 7 & 9.7 & 9.7 & 90.3 \\
\hline $\begin{array}{l}\text { government } \\
\text { officials }\end{array}$ & 7 & 9.7 & 9.7 & 100.0 \\
\hline Total & 72 & 100.0 & 100.0 & \\
\hline
\end{tabular}

\section{Descriptive Statistics}

The mean values and the standard deviations of the measured variable were analysed and presented in the table below. 
Table 2 Descriptive Statistics

\begin{tabular}{|l|l|l|l|l|}
\hline & $N$ & Mean & Std. Deviation & Std. Error Mean \\
\hline Acceleration & & & & \\
Infrastructure & 72 & 4.1806 & 1.28179 & .15106 \\
Development & 72 & 4.1250 & .93353 & .11002 \\
Economic effect & 72 & 4.5556 & .88634 & .10446 \\
Tourism effect & 72 & 3.8750 & 1.45290 & .17123 \\
Cost effect & 72 & 4.4861 & .93437 & .11012 \\
Social and political impact & 72 & 1.7083 & 1.31554 & .15504 \\
Reforms in the & 72 & & \\
government & & & & \\
\hline
\end{tabular}

Source: Data from Survey Questionnaire

\section{Model Specification}

A regression model was used to measure the significance of the $2022 \mathrm{FWC}$ on infrastructure development. The measure for infrastructure development was the mean of the responses grouped in a one-factor score for each respondent. The independent variables were the social and political effect, economic effect, tourism effect and cost effect. The coefficients estimates of the variable are shown below (Table 4). The model was a good fit, as seen below, with $50 \%$ of the independent variables explaining the dependent variable. The coefficient estimates that were all positive except for occupation. A $1 \%$ change in the economy due to the World Cup causes a $0.24 \%$ increase in infrastructure development. A $1 \%$ increase due to tourism revenues causes a $0.11 \%$ change in infrastructure development. A $1 \%$ increase in the cost of expenditures due to the FWC causes a $0.4 \%$ increase in infrastructure development. A $1 \%$ increase in the social and political impact caused by the FWC causes a $0.25 \%$ increase in infrastructure development

Table 3 Coefficient Estimates

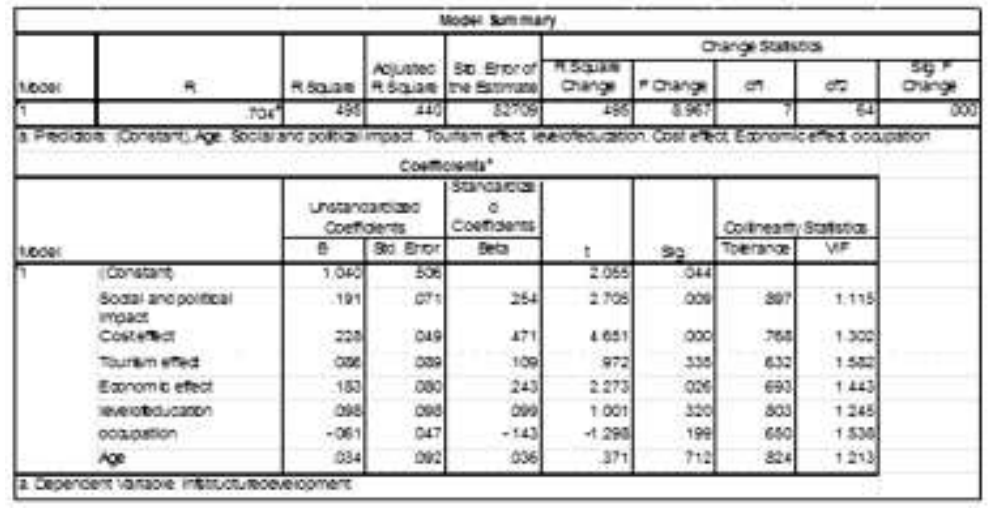




\section{Hypothesis and Questionnaire Analysis}

The questions asked to the respondents were used to determine the significance of the 2022 FWC infrastructural development in the country. The analysis involved using the sample means to determine the relevance of the hypothesis.

\section{Acceleration of Infrastructure}

The question asked was whether the Hosting of the 2022 FIFA world cup accelerates changes in infrastructure development in the country. A higher percentage of the participants agreed that the 2022 FWC would accelerate infrastructure development in the country with a mean of 4.18 , as seen in Table 4 above.

Figure 4 Acceleration of Infrastructure

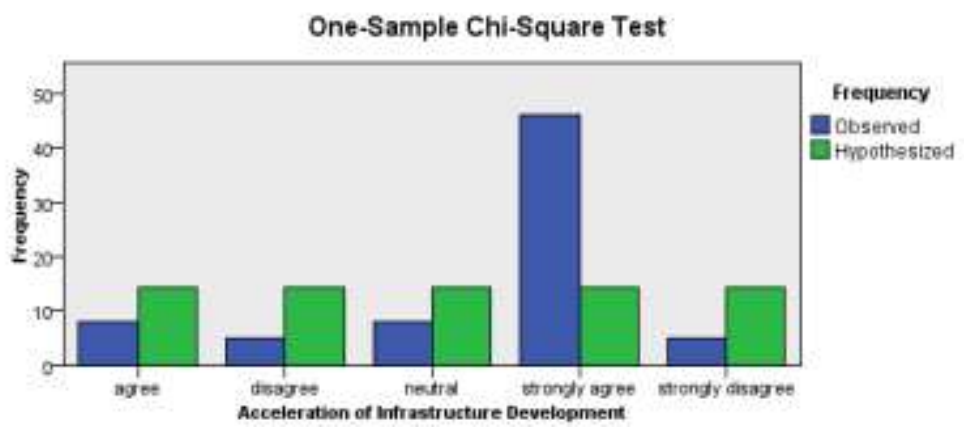

\section{Hypothesis 1}

Using a one-sample Chi-Square test, the mean of the variable acceleration of infrastructure was used to test for their significance.

$\mathrm{H} 1$ : being the mean is not different from zero and $\mathrm{H} 2$ : being the mean is statistically different from zero. This meant that accepting the null hypothesis that infrastructure development is not accelerated by mega sporting events while rejecting is means that infrastructure development in Qatar is accelerated by the 2022 FWC.

$\mathrm{H} 1: \mu=0$, the FWC does not accelerate infrastructure development.

$\mathrm{H} 2: \mu \neq 0$, the FWC accelerates infrastructure development.

With the confidence of $95 \%$ the significance $<0.05$; therefore, the study rejected the null hypothesis and concluded that the mean is different from zero. Hence the conclusion that the 2022 FWC accelerates infrastructure development.

\section{Positive Impacts of Mega Sporting Events}

Questions were asked on the Economic and tourism effect of the mega sporting events to determine whether the 2022 FWC would impact the infrastructure of the country positively. The participants were asked about whether they thought the 2022 FWC would promote local business and increase tourism effects. Both the graphs had strongly agreed and agreed as the highest responses, hence showing that the majority of the respondents felt that the 2022 FWC would 
impact the economy positively and enhance further development of infrastructure as seen in fig 5 below. The means were both higher than 3; hence most people agreed with the positive economic and tourism effect (see Table 4).

Figure 5 Economic and Tourism Effects

One-Sample Chi-Square Test

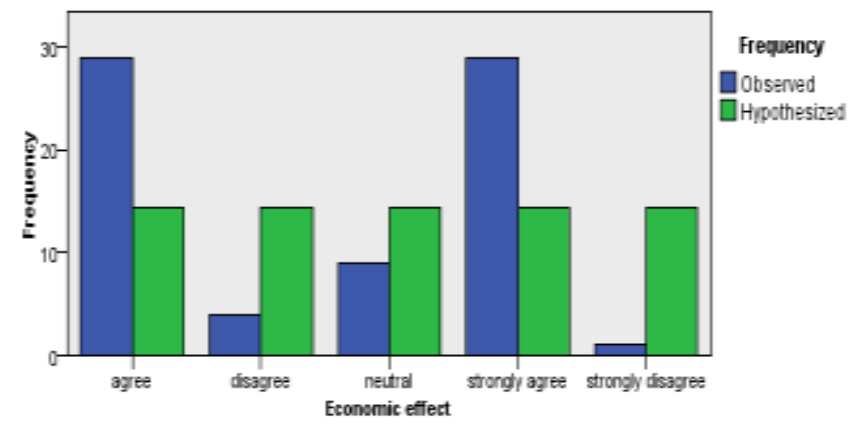

One-Sample Chi-Square Test

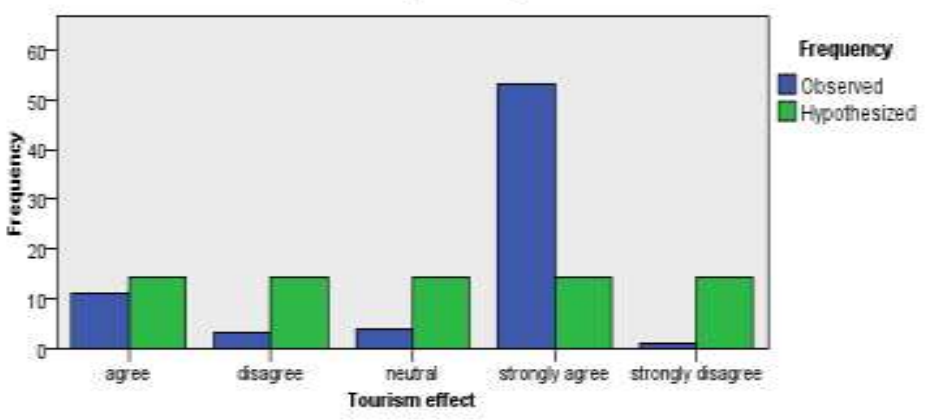

\section{Hypothesis 2}

Using a one-sample chi-test, the means of the variables, economic effect and tourism effect were used to test for their significance.

The hypothesis tested whether the 2022 FWC in Qatar has a positive impact or not on the infrastructure of the country.

$\mathrm{H} 1: \mu=0$, the FWC does not have a positive effect on the economic and tourism infrastructure of the country.

$\mathrm{H} 2: \mu \neq 0$, the FWC has a positive impact on the economic and tourism infrastructure of the country.

With the confidence level of $95 \%$ and the siege $<0.05$; therefore, the study rejected the null hypothesis and concluded that the mean is statistically different from zero. Hence the conclusion that the 2022 FWC has a positive effect on the economic and tourism infrastructure of the country at a 95\% significance level.

\section{Cost Effects of Mega Sporting Events on Infrastructure}

The question asked to the respondents to determine the cost-effectiveness of the 2022 FWC, was whether the expenditure on infrastructure should be spent 
to improve the quality of the lives of people and not on the 2022 FIFA World cup. The data from table 2 shows that the mean of the variable cost effect was 3.8. This was greater than 3; meaning most people agreed that the cost of the infrastructure development should be spent on the livelihoods of people rather than the FWC.

Figure 6 Cost Effect of the FWC

One-Sample Chi-Square Test

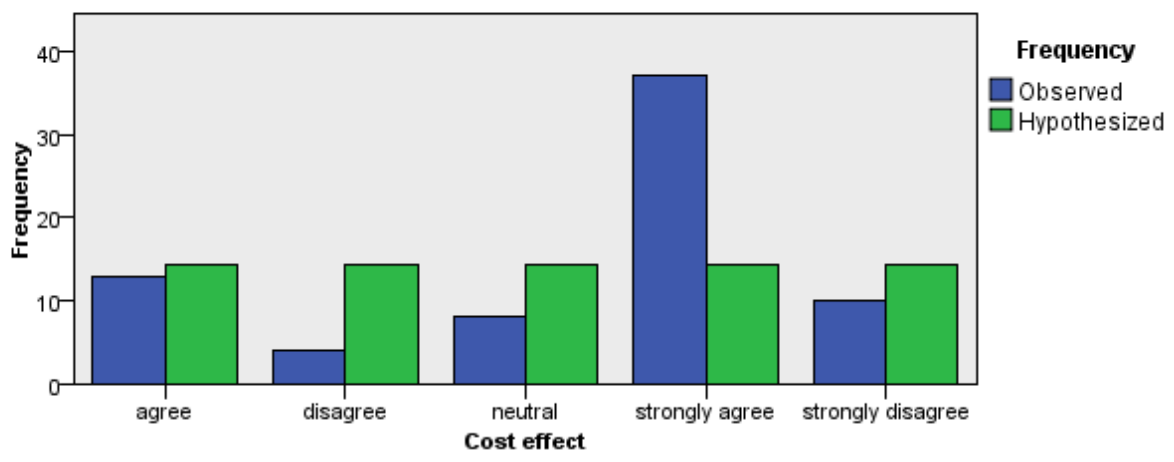

Hypothesis 3

Using a one-sample chi-Square test, the mean of the variable cost effect was used to test for their significance.

The hypothesis tested whether the FWC cost of the infrastructure of the country was necessary.

$\mathrm{H} 1: \mu=0$, the FWC cost of the infrastructure of the country is necessary.

$\mathrm{H} 2: \mu \neq 0$, the FWC cost of the infrastructure of the country is not necessary.

With the confidence of $95 \%$ the significance was such that sig<0.05; therefore, the study rejected the null hypothesis and concluded that the mean is statistically different from zero. Hence the conclusion that the costs of the 2022 FWC affects infrastructure development in Qatar.

\section{Social and Political Effects of the 2022 FWC}

The questions asked to determine the social impact of the 2022 FWC was; whether the respondents thought that the world cup would increase the cooperation of the country with other nations and whether it will promote reforms in most of the sharia laws. According to the analysed data (See Table 2) the mean of 4.4 showed that a higher number of the respondents agreed to the fact that the world cup would cause positive social and political infrastructure changes to the country. 
Figure 7 Social and Political Infrastructural Impacts

One-Sample Chi-Square Test

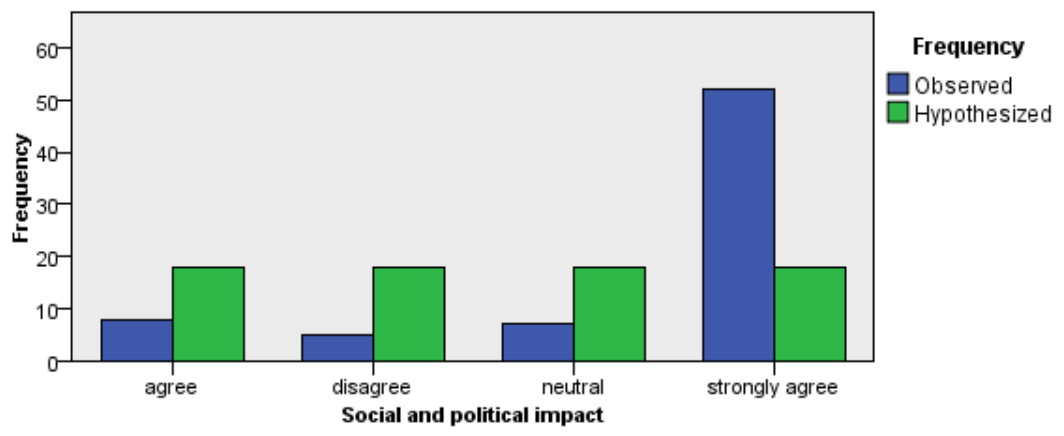

\section{Hypothesis 4}

Using a one-sample Chi-Square test, the mean of the variable, social and political infrastructure effects were used to test for their significance.

The hypothesis tested whether the 2022 FWC affected the social and political infrastructure developments of Qatar negatively by

$\mathrm{H} 1: \mu=0$, the 2022 FWC affects the social and political infrastructure developments in Qatar negatively

$\mathrm{H} 2$ : $\mu \neq 0$, the $2022 \mathrm{FWC}$ does not affect the social and political infrastructure developments in Qatar adversely.

With the confidence of $95 \%$, the significance was such that sig< 0.05 ; therefore the study rejected the null hypothesis and concluded that the mean is statistically different from zero. Hence the conclusion that the FWC affects the social and political infrastructure developments in Qatar positively.

\section{Tests for Reliability and Collinearity}

The response test for reliability was done using Cronbach's alpha test for internal consistency. The deletion of the variable sharia law reforms helped in scaling the responses hence their reliability ${ }^{34}$. The Cronbach's a value was found to be 0.616 . According to Hair et al. ${ }^{35}$ it's considered a reliable scale. The author recommends a Cronbach's alpha cutoff point of 0.55 . The VIF collinearity factor analysis also showed there was no multicollinearity as the VIF did not exceed 4.0 and the tolerance was not less than $0.2 .^{36}$

\footnotetext{
34 "Stats 2: Reliability". 2020. Vault.Hanover.Edu. https://vault.hanover.edu/ altermattw/courses/220/spss/reliability/reliability-2.html. ${ }^{35}$. Hair, J.F., RE. Anderson, RL. Tatham and W.G. Black, 1998. Multivariate Data Analysis. 5th Edn, Prentice Hall, New Jersey, USA, ISBN-JO: 0138948585, pp: 768. ${ }^{36}$. Hair JF, William CB, Barry JB, Rolph EA (2010). Multivariate data analysis 7th Edition.
} 
The significance of mega sporting event on infrastructure development: ...

Table 4 Collinearity Status

\begin{tabular}{|l|l|}
\hline Collinearity Statistics & VIF \\
\hline Tolerance & \\
& \\
0.68 & 1.472 \\
0.636 & 1.573 \\
0.774 & 1.291 \\
0.86 & 1.163 \\
0.759 & 1.318 \\
0.69 & 1.449 \\
0.685 & 1.459 \\
0.943 & 1.06 \\
\hline
\end{tabular}

\section{Discussion of Findings}

The results from the four hypotheses tested were found to be statistically significant at a Chi-square test significance of sig $<0.05$. This implied that the first hypothesis, the researcher rejected the null hypothesis that mega sporting events do not increase the rate at which infrastructural developments take place in host countries. This allowed the researcher to conclude that mega sporting events, in this case, the 2022 FWC will accelerate infrastructure development in Qatar. The second hypothesis was also rejected, therefore, concluding that infrastructural developments of host countries are affected positively by mega sporting events, i.e. the 2022 FWC will increase infrastructural developments in Qatar. The third hypothesis also was rejected, accepting the alternative hypothesis stating that the costs of expenditure on the 2022 FWC affect the infrastructural developments negatively. This was because the citizens would bear the costs, through taxpayers' money, which was considered not worth it.

The last hypothesis tested was whether the social and political infrastructure developments of host cities are affected negatively by Mega-sporting events. This was also rejected, concluding that the 2022 FWC will have a positive effect on the social and political infrastructure of the country. The estimation of the model was such that: $1 \%$ change in the economy due to the World Cup would cause a $0.24 \%$ increase in infrastructure development. Also, a $1 \%$ increase due to tourism revenues would cause a $0.11 \%$ change in infrastructure development. Moreover, a $1 \%$ increase in the cost of expenditures due to the FWC would cause a $0.4 \%$ increase in infrastructure development. A $1 \%$ increase in the social and political impact caused by the FWC causes a $0.25 \%$ increase in infrastructure development. This meant that the 2022 FWC in Qatar would influence the infrastructural development positively in all fronts. 


\section{SUMMARY, CONCLUSION, AND RECOMMENDATIONS Summary of the Research}

Concerns have been raised about the significance of mega sporting events in infrastructure development of a country. Those disputing its benefits such as Matheson ${ }^{37}$ insist such benefits outweigh the costs involved. Different forms of impact seem to be generated from mega sporting events on varying degrees. However, there is very little research on the significance of mega sporting events on infrastructure development. The research problem, therefore, was to establish the significance of these effects and changes in infrastructural development caused by mega sporting events. The research objectives set were; first, to provide an understanding of how the infrastructural developments are affected by mega sporting events. To measure these effects, the responses were grouped in the form of social and political impact, tourism effects, economic effects, and cost effects. The second objective was to analyse the contribution of the 2022 FIFA World Cup to the infrastructural development of Qatar. This was measured by the mean of different responses that measured infrastructural changes in Qatar. And thirdly, it was to assess if the effects of the 2022 FIFA World Cup in Qatar were effective insofar as infrastructural developments are concerned.

The conceptual and theoretical framework of the research was based on the model of infrastructure developments and its relationship with mega sporting effects. With the first objective, a previous number of studies established the impact of mega sporting events in infrastructure development. Most studies agreed on the positive economic results of the mega sporting events. However, certain researches claimed that this was dependent on the type of mega sporting effects and the level of development of the country. Various studies supported the tourism effects, though certain researchers found claims that tourism benefits did not change even after a mega sporting event took place. The cost effects of mega sporting events were much criticised by different researchers claiming that the excessive spending on infrastructure was not necessary. Most studies agreed on the social and political benefits that came with mega sporting events, even with the substantial infrastructural costs. A few cited no changes in the host cities, social and political status after a mega sports event.

The researchers also recorded significant changes that took place in countries because of the mega sports events. Places like South Africa had overall gentrification of its public spaces as well as the revamp of its transportation systems. The study also by Chen Ling showed the changes in the infrastructure of Beijing during their Olympics. To perform the research, online survey

\footnotetext{
${ }^{37}$. Matheson, Victor, "Assessing the infrastructure impact of mega-events in emerging economies" (2012). Economics Department Working Papers. Paper 8.
} 
questionnaires were used. The analysis was quantified with the data analysed by the use of the SPSS software. A pilot study was conducted to check whether the questionnaires were clearly understood by the respondents. The questions were found to be non-ambiguous. The questions took the form of a 5-point Likert scale to measure both the effects of the FWC and the significant changes in infrastructure. A Cronbach's analysis was carried out to test for reliability, and the scale was found to be reliable. The average of the responses was used to determine infrastructure development caused by the 2022 FWC. The VIF test for collinearity was conducted, and there was no collinearity present. Four hypotheses were formulated to achieve the objectives of the research. A onesample Chi-square test was conducted on the variables to perform hypotheses tests for the significant effects on infrastructure development. Variables that were found insignificant were not included in the model. A model was created to analyse the relationship between the 2022 FWC and the infrastructure development of Qatar.

\section{Conclusions and Recommendations}

From the hypothesis tests conducted, the first hypothesis was rejected, and it was found that the 2022 FWC will accelerate the development of infrastructure in Qatar. The second hypothesis was also proven wrong, establishing that the 2022 FWC does have a positive economic effect on the infrastructure of Qatar. The third hypothesis test done deduced that the cost effects of 2022 FWC have a negative impact on the host cities. The fourth hypothesis determined that there was a significant positive social and political effect caused by the 2022 FWC on Qatar. The model established a significant positive economic impact of the FWC on infrastructure development. This was similar to the research by Gouher et al., ${ }^{38}$ which also found out that mega sporting events have a positive impact on tourism and development of infrastructure. The model also established that there was a significant positive social and political effect caused by mega sports events on infrastructure development of Qatar. This was also in congruence with research by Chaberek et al. and Gong, who emphasised on the focus of the social impacts of mega sports events and the political impacts, respectively. The cost effect, however, was also found to have a positive effect on infrastructure development. This meant that more costs on the infrastructure would increase infrastructure development. Nevertheless, comments from the responses were against this increase in expenditure on the 2022 FWC. This was in-line with research by Chen Ling that supported an increase in infrastructure development

\footnotetext{
38. Amponsah, Christian Tabi, Gouher Ahmed, Manoj Kumar, and Samuel Adams. "The business effects of mega-sporting events on host cities: an empirical view." Problems and Perspectives in Management 16, no. 3 (2018): 324-336. Retrieved from: http://dx.doi.org/10.21511/ppm.16(3).2018.26
} 
to promote the Beijing Olympics to be more beneficial. It is recommended that further research should be carried on the cost effects of the mega sporting events. This will help with the disparity in opinions among researchers. In line with research conducted in the Middle East (e.g. Hunaiti et al., 2009; Karajeh \& Maqableh, 2014; Al-Dmour et al., 2015; Masa'deh, 2016; Bazazo et al., 2017; Aqqad et al., 2019; Al-Dmour et al., 2020), more empirical studies similar to this, one should also be conducted with much larger samples as compared to this research.

\section{References}

2022 FIFA world cup awarded to Qatar, Dec 2010: Retrieved from https://www.fifa.com/news/2022-fifa-world-cup-awarded-qatar-1344500

Al-Dmour, R., Al Haj Dawood, E., \& Al-Dmour, H. (2020). The effect of customer lifestyle patterns on the use of mobile banking applications in Jordan. Int. J. Electronic Marketing and Retailing, 11(3), 239-258.

Al-Dmour, R., Obeidat, B., \& Almajali, D. (2015). The practice of HRIS applications in business organizations in Jordan: An empirical study. 4th Scientific \& Research Conference on New Trends in Business, Management and Social Sciences (COES\&RJ-TK15/1).

Adam Rasmi, Beer is giving 2022 World Cup host Qatar a headache, 2019. Retrieved from: https://qz.com/1663896/beer-is-giving-2022-world-cup-hostqatar-a-headache/

Agénor, Pierre-Richard. (2010). A Theory of Infrastructure-Led Development. Journal of Economic Dynamics and Control. 34. 932-950. 10.1016/j.jedc.2010.01.009.

Amponsah, Christian Tabi, Gouher Ahmed, Manoj Kumar, and Samuel Adams. "The business effects of mega-sporting events on host cities: an empirical view." Problems and Perspectives in Management 16, no. 3 (2018): 324-336. Retrieved from: http://dx.doi.org/10.21511/ppm.16(3).2018.26

Angeliki, Mavropoulou, Hatzimanouil Dimitrios, Gkagkanas Kostas, and Kanioglou Aggelos. "Evaluation of the new Belgrade summer cup handball 2018 and the impact in the city of Belgrade." Journal of Physical Education 5, no. 2 (2018): 1-8., Published by American Research Institute for Policy Development https://doi.org/10.15640/jpesm.v5n2a1 
Aqqad, N., Obeidat, B., \& Tarhini, A. (2019). The relationship among emotional intelligence, conflict management styles, and job performance in Jordanian banks. International Journal of Human Resources Development and Management, 19(3), 225-265.

Baade, Robert A., and Victor A. Matheson. "The quest for the cup: assessing the economic impact of the world cup." Regional studies 38, no. 4 (2004): 343-354., DOI: $10.1080 / 03434002000213888$

Baade, Robert A., Robert W. Baumann, and Victor A. Matheson. "Assessing the economic impact of college football games on local economies." Journal of Sports Economics 9, no. 6 (2008): 628-643.

Bazazo, I., Alansari, I., Alquraan, H., \& Alzgaybh, Y. (2017). The influence of total quality management, market orientation and e-marketing on hotel performance. International Journal of Business Administration, 8(4), 79.

Chaberek-Karwacka, Grażyna, and Julia Ziółkowska. "The impact of mega events on the local economic development through the development of social capital." Journal of Geography, Politics and Society 7, no. 4 (2017): 25-31. 10.4467/24512249JG.17.034.7634

Dunmore, Tom. Historical dictionary of soccer. Scarecrow Press, 2011.

Finer, J. (2002, March 7). The grand illusion. Far Eastern Economic Review, 165 (9), pp. 32-36

Fourie, Johan, and Maria Santana-Gallego. "The impact of mega-events on tourist arrivals." Stellenbosch, Stellenbosch University (2010).

Gong, Qi. "The Positive and Negative Economic Contributions of Mega-sporting Events to Local Communities." (2012).

Gravetter, Frederick J., and Lori-Ann B. Forzano. Research methods for the behavioural sciences. Cengage Learning, 2018.

Hair, J.F., RE. Anderson, RL. Tatham and W.G. Black, 1998. Multivariate Data Analysis. 5th Edn, Prentice Hall, New Jersey, USA, ISBN-JO: 0138948585, pp: 768.

History-Croatian Football Federation. 2020. Hns-Cff.Hr. https://hnscff.hr/en/hns/about-us/history/ 
Hosting Mega Sporting Events - A Boost For The Host Nation's Economy?. 2018. Medium. https://medium.com/@valustrat/hosting-mega-sporting-events-aboost-for-the-host-nations-economy-af0df5e95874.

Hunaiti, Z., Mansour, M., \& Al-Nawafleh, A. (2009). Electronic commerce adoption barriers in small and medium-sized enterprises (SMEs) in developing countries: The case of Libya. IBIMA Business Review, 2(5), 37-45.

Joan C. Henderson (2014) Hosting the 2022 FIFA World Cup: opportunities and challenges for Qatar, Journal of Sport \& Tourism, 19:3-4, 281-298, DOI: 10.1080/14775085.2015.1133316

Karajeh, H., \& Maqableh, M. (2014). Security of cloud computing environment. The 23rd IBIMA Conference on Vision 2020: Sustainable Growth, Economic Development, and Global Competitiveness, USA, 2202-2215.

Ling, Chen. "Mega-events and infrastructure improvements: The Case of the Olympic Games in Beijing 2008." (2007). Retrieved 26 April 2020, from https://lup.lub.lu.se/student-papers/search/publication/1325053

Masa'deh, R. (2016). The role of knowledge management infrastructure in enhancing job satisfaction at Aqaba five star hotels in Jordan. Communications and Network, 8(4), 219-240.

Matheson, Victor, "Assessing the infrastructure impact of mega-events in emerging economies" (2012). Economics Department Working Papers. Paper 8. http://crossworks.holycross.edu/econ_working_papers/8

Nate Berg, The Infrastructural Benefit of South Africa's World Cup, 2010. Retrieved from https://www.planetizen.com/node/44124

Qatar Infrastructure, Power, And Communications, Information About Infrastructure, Power, And Communications In Qatar. 2020. Nationsencyclopedia.Com.

https://www.nationsencyclopedia.com/economies/Asia-and-the-Pacific/QatarINFRASTRUCTURE-POWER-AND-COMMUNICATIONS.html.

Robby Robertson, The Economic Impact of Sports Facilities, "United States Sports Academy-" America's Sports University." The Sport Digest - ISSN: 1558-6448 http://thesportdigest.com/archive/article/economic-impact-sports-facilities 
The significance of mega sporting event on infrastructure development: ...

Scharfenort, Nadine. "Urban development and social change in Qatar: the Qatar National Vision 2030 and the 2022 FIFA World Cup." Journal of Arabian Studies 2, no. 2 (2012): 209-230., DOI: 10.1080/21534764.2012.736204

Šimić-Banović, Ružica, Ana Jurčić, and Milan Petronijević. "Hosting mega sport events in a small country: The (real) impact on the development-cases of Croatia and Serbia." Megatrend revija 14, no. 2 (2017): 273-290. 10.5937/MegRev1702273S

The 2018 FIFA World Cup In Russia - Circuses Instead Of Bread?. 2018. OSW Centre For Eastern Studies. https://www.osw.waw.pl/en/publikacje/oswcommentary/2018-09-17/2018-fifa-world-cup-russia-circuses-instead-bread. 